\title{
PROSES DAN KESAN KEMASUKAN BRITISH KE SINGAPURA 1819: CATATAN ABDULLAH ABDUL KADIR MUNSYI DALAM HIKAYAT ABDULLAH
}

\author{
Mardiana Nordin
}

\begin{abstract}
Hikayat Abdullah is a work in Malay literature written by Abdullah bin Abdul Kadir Munsyi. Unlike other works written before the 20th century that tend to be biases towards royal and aristocratic societies, Hikayat Abdullah takes a different attitude. Abdullah seems to write an auto-biography specifically about his life experiences from childhood to adult and his involvement in the lives of British officers. One subject caught his interest, that is the policies and methods of administration of colonial officers who were close to him such as William Farquhar and Thomas Stamford Raffles. Therefore, he ventured to write on the episode of British arrival in Singapore in 1819 with precision and much details. Undoubtedly, the arrival of the British in Singapore during that year is a very important historical event. Abdullah details his writing over the previous year and extends the story until a few years later. Thus, the study of these episodes through Hikayat Abdullah could provide an new understanding of the period.
\end{abstract}

\section{Pengenalan}

Karya-karya pensejarahan Melayu khususnya yang lahir sebelum abad ke-20 lazimnya memiliki beberapa ciri yang hampir sama. Suatu aspek yang paling ketara ialah ciri istana centric yang tebal dalam pemaparan peristiwa, kecenderungan tafsiran dan tema-tema kepengarangan yang 
dipilih. Kerana itulah, karya-karya agung Melayu seperti Sulalatus Salatin, Tuhfat al-Nafis, Hikayat Merong Mahawangsa, Hikayat Pahang, Hikayat Seri Kelantan, Syair Sultan Zainal Abidin, Misa Melayu dan lain-lain karya seumpama dengannya menjadi rujukan utama dalam memahami senario politik negeri-negeri Melayu khususnya tentang institusi kesultanan sebelum abad ke-20.

Selain itu, pada masa yang sama peneliti sememangnya berhadapan dengan situasi kekangan sumber ekoran pilihan 'sumber Melayu' yang sangat terhad dan masalah memahami sumber kolonial kerana isu bahasa (terutama Portugis dan Belanda). Tidak dinafikan, sifat kepengarangan yang sedemikian lahir kerana pujangga-pujangga Melayu itu sendiri sebahagian besarnya lahir dalam dunia istana, membesar, mendapat pendidikan malahan berkhidmat dengan institusi istana. Justeru, selain dorongan bias, pasti juga pengalaman dan pengetahuan tentang persekitaran istana lebih tebal dan arif dalam kalangan mereka dan maklumat itulah yang disalurkan dalam karya mereka.

\section{Latar Belakang Abdullah Abdul Kadir dan Hikayat Abdullah}

Di dalam rancaknya kelahiran karya-karya pensejarahan Melayu tradisi, lahir sebuah karangan Melayu yang memiliki hampir 180 darjah berbeza sifatnya daripada karya-karya di atas. Biarpun lahir dalam tempoh yang hampir sama dengan Tuhfat al-Nafis misalnya, Hikayat Abdullah lahir dalam idea yang menyimpang dari arus perdana. Tidak berkisar tentang istana dan tidak juga memuja-muja pihak istana, pengarang Hikayat Abdullah ialah seorang individu berpendidikan yang tidak tergolong sebagai golongan bangsawan atau kerabat istana. Pengarang lebih banyak memaparkan senario kemasyarakatan tetapi juga banyak menggarap perjalanan hidup pegawai-pegawai kolonial yang dekat dengan kehidupannya. Sekiranya karya-karya lain mengetengahkan peranan raja, putera raja, pembesar-pembesar istana dalam hal-ehwal negeri Melayu seperti peperangan, hubungan diplomatik, perkahwinan, konflik dalaman dan juga ketokohan raja, Hikayat Abdullah lebih menonjolkan dasar-dasar pegawai kolonial dalam pentadbiran mereka di Tanah Melayu.

Dihasilkan pada pertengahan pertama abad ke-20, Hikayat Abdullah selesai dikarang pada tahun 1845. Selanjutnya, karya ini pertama kali diterbitkan pada tahun 1849 di Singapura dalam tulisan jawi cetak batu. Hikayat Abdullah diulang cetak beberapa kali misalnya pada tahun 1882 dan 1887-1897. Hikayat Abdullah juga pernah dicetak dalam bentuk dua jilid. Menyedari akan kepentingan dan nilai yang tinggi, teks ini kemudian diterbitkan pula oleh penerbit Pustaka Antara pada tahun 
1907 dan digunakan sebagai buku teks di sekolah-sekolah Melayu. Hikayat Abdullah menjadi teks sastera Melayu pertama yang diterbitkan secara komersil.

Seperkara yang turut membezakan di antara Hikayat Abdullah dengan karya-karya lain sezamannya adalah bentuk kepengarangan penulisan ini. Umumnya, biarpun karya ini mengandungi pelbagai peristiwa sejarah yang berlaku pada abad ke-19, namun karya ini boleh dikategorikan sebagai sebuah autobiografi Abdullah iaitu pengarangnya sendiri. Kenyataan ini boleh dibuktikan sendiri melalui kata-kata Abdullah di dalam tulisannya yang berbunyi:

Maka adalah aku karangkan akan kitab ini dari hal hikayat diriku, maka ku namai akan dia Hikayat Abdullah. Maka adalah ku rencanakan dalamnya dari zaman moyangku sampailah kepada masa aku diperanakkan oleh ibuku... sehingga barang yang ku lihat dan yang ku dengar daripada segala hal ehwal zaman-zaman yang tersebut itu, baik dalam negeri Melaka, baik dalam negeri Singapura, adalah kusebutkan dalam hikayatku ini, iaitu sehingga kepada tarikh pengabisan kitab ini. ${ }^{1}$

Abdullah bin Abdul Kadir Munsyi merupakan seorang individu yang bukan berasal dalam kalangan istana tetapi berkemahiran tinggi dalam dunia pengarangan. Beliau dilahirkan pada 12 Ogos 1796 di Melaka. Ibu Abdullah bernama Salmah iaitu merupakan isteri kedua kepada bapanya, Abdul Kadir Ibrahim. Melalui Hikayat Abdullah ini, jelas tergambar Abdullah menggarap karya dengan beberapa gaya baru dan tidak lagi menjurus kepada pihak pemerintah. ${ }^{2}$

Hikayat Abdullah boleh dikategorikan sebagai sebuah karya yang bersifat auto-biografi (walaupun pada masa yang sama mengandungi juga begitu banyak perspektif Abdullah yang meluas tentang aspek kemasyarakatan dan personaliti individu). Di awal-awal pengarangan, Abdullah memerihalkan dengan panjang lebar perihal moyangnya yang bernama Syeikh Abdul Kadir iaitu seorang berbangsa Othmani dari Yaman dan merupakan seorang guru bahasa dan agama. Moyangnya itu telah berhijrah ke Nagore di India lalu berkahwin dengan seorang wanita Tamil dan mendapat empat orang putera. Salah seorangnya (yang sulung) diberi nama Muhamad Ibrahim iaitu datuknya. Datuk Abdullah kemudian berhijrah ke Melaka dan berkahwin di sana. Hasil perkahwinan ini, Syeikh Abdul Kadir iaitu bapa Abdullah dilahirkan. Di dalam Hikayat Abdullah juga menyatakan dengan jelas, Syeikh Abdul Kadir menjalankan aktiviti perniagaan di samping mengajar ilmu agama, bahasa, kira-kira serta pernah menjadi khatib di Sungai Baru, Melaka. 
Selanjutnya, kandungan Hikayat Abdullah secara jelas memperincikan pengalaman dan kehidupan Abdullah sejak dari kecil sehingga dibesarkan khususnya di Melaka. Oleh itu, melalui teks ini beliau menggambarkan dirinya dibesarkan dalam suasana yang penuh keilmuan dan berdisiplin tinggi. Abdullah didedahkan dan diajar dengan ilmu-ilmu bahasa sehingga menguasai Bahasa Melayu, Tamil, Hindi dan Cina. Beliau juga diberi kemahiran dalam teknik-teknik penulisan kitab, surat, kira-kira (akaun) dan lain-lain. Dalam memperihalkan episod demi episod pengajiannya, Abdullah menggambarkan dirinya sebagai seorang yang 'cepat belajar', mudah menguasai kemahiran dan berkeyakinan tinggi. Suatu sifat pengarangan yang agak 'membangga diri' yang pastinya tidak terkandung dalam karya pensejarahan Melayu yang lain. Namun, hakikatnya seiringan dengan situasi inilah, Abdullah mula digelar 'Munsyi' yang membawa erti guru atau pengajar bahasa-bahasa.

Apabila meningkat dewasa dan mula melibatkan diri dalam dunia pekerjaan, Abdullah juga mempelajari Bahasa Inggeris daripada Milne iaitu seorang paderi British yang datang ke Melaka pada tahun 1823. Pada masa yang sama, Abdullah juga mengajar pula Bahasa Melayu kepada paderi tersebut. Ketika itu Abdullah baru berusia kira-kira 24 tahun. Sememangnya Abdullah banyak memainkan peranan mengajar Bahasa Melayu kepada pegawai-pegawai barat. Seorang lagi orang barat yang disebutkan dalam Hikayat Abdullah bernama Peach Keasberry dari Amerika. Keasberry dan isterinya turut mempelajari Bahasa Melayu dengan Abdullah. Selain itu, banyak kali dalam karya ini Abdullah menyenaraikan nama orang-orang asing yang turut mempelajari Bahasa Melayu dengannya sama ada di Melaka mahupun Singapura. Antaranya ialah Paderi Thompson dan guru bahasa Cina kepada Milne iaitu Li Siang Sin. Selain itu disebutkan juga Medhurst dan Tuan Beighton yang menuntut bahasa Melayu dengan Abdullah. Ketika di Singapura, apabila pulau ini didatangi ramai saudagar muda dari Amerika, mereka turut mempelajari Bahasa Melayu dengan Abdullah. Sebagaimana yang dicatatkan dalam Hikayat Abdullah:

Sebermula maka kembalilah pula aku menceretakan hal diriku sendiri. Maka adalah pula kira-kira tiga tahun lamanya aku duduk tetap mengajar Bahasa Melayu kepada saudagar-saudagar Inggeris yang muda-muda yang baharu datang ke Singapura. Maka tiadalah sempat aku hendak sebutkan nama tuan-tuan itu sekalian karena terlalu banyak, tetapi adalah setengah daripada mereka itu Tuan Boustedt, dan Tuan Benjamin Butler, dan Tuan Sykes dan Tuan Read dan Tuan Patton dan Tuan Thorrington dan Tuan John Morgan dan Tuan Kerr dan Tuan Watt dan Tuan Macdonald dan Tuan Purvis dan Tuan Armstrong kedua beradik, dan Tuan Roger dan 
Tuan Martin dan Tuan Gurney dan Tuan Dyce dan Tuan Hansen dan Tuan Gilbert MacMicking dan Tuan Cretemping. Lagi entah beberapa ratus tuan-tuan orang putih Inggeris dan Perancis yang $\mathrm{ku}$ ajar, tiadalah aku teringat nama-nama mereka itu. Maka lain pula perempuan-perempuan Inggeris dan Merikan dan anak darah-darah mereka itu sekalian yang ku ajar dalam negeri Singapura. ${ }^{3}$

Biarpun setelah berkhidmat di Singapura, Abdullah turut menggambarkan dirinya masih diperlukan sebagai guru bahasa di Melaka. Teks ini mencatatkan:

Hatta maka dalam hal ku duduk mengajar di Singapura itu, maka datanglah surat dari Melaka, iaitu daripada paderi Humpreys dan paderi Kidd dan paderi Collie, iaitu sekalian memanggil aku pulang ke Melaka, karena dalam Kolej Melaka seorang pun tiada ada guru yang mengerti bahasa Inggeris dan bahasa Melayu, karena di sana ada surat-surat dan kitab-kitab bahasa Melayu, karena mereka itu hendak belajar. ...

Maka adalah selang tiga empat bulan lagi, datanglah pula surat-surat daripada tuan-tuan itu meminta aku pulang juga ke Melaka serta disebutkannya dalam surat itu, katanya, "Tuan sudah lupakah akan kasih Tuan Doktor Morrison dan Tuan Milne sudah mengajar tuan? Maka sekarang sudah menjadi pandai, maka tuan tiada endahkan Kolej Melaka lagi. Maka ada pekerjaannya kolej dipanggil, tuan tiada mau datang."

Adapun sebab aku terkenangkan baiknya Tuan Morrison dan Tuan Milne itu, maka pada hari itu juga aku meminta pada tuan-tuan yang di Singapura hendak ke Melaka serta kuunjukkan surat yang datang dari Melaka itu. Maka tuan-tuan itu pun masamlah muka oleh tiada berdaya. Maka diberinyalah izin. Maka kutinggalkanlah pekerjaan yang di Singapura, lalu pergilah ke Melaka. Maka setelah sampai aku ke Melaka, maka sukacitalah tuan-tuan itu katanya, "Jikalau tiada sahaya sekalian sebutkan nama Tuan Morrison dan Tuan Milne, nescaya tuan tiada mau datang." 4

Garapan di atas jelas menggambarkan bentuk kepengarangan yang berbeza daripada tradisi kepengarangan Melayu yang lain apabila beliau secara optimis memaparkan kelebihan dan 'keistimewaan' dirinya sendiri. Abdullah juga menggambarkan sepanjang hayatnya beliau pernah berkhidmat dan melakukan pelbagai pekerjaan. Selain menjadi guru bahasa Melayu seperti yang diterangkan di atas, Abdullah juga pernah menjadi guru agama, kerani, pembantu pegawai British (merangkap Setiausaha), pembantu penyelidik dan sebagainya. Seperkara lagi, aktiviti yang banyak dilakukan oleh beliau ialah penterjemahan dan juga salin-menyalin. Memandangkan kemahiran 
beliau dalam pelbagai bahasa, Abdullah pernah menterjemahkan karyakarya sastera seperti karya sastera Hindu berjudul Pancatanderan ke bahasa Melayu yang kemudian dijudulkan sebagai Galila dan Damina. Penterjemahan karya ini dilaksanakan dengan bantuan rakannya Tambi Muttu Birapattar dari Kampung Masjid Keling. Abdullah turut mengakui beliau menyalin dan menulis semula ke bahasa Melayu yang lebih kemas, terhadap kitab Injil Matius dan Kitab Segala Rasul. Selain itu, Abdullah pernah mengarang sebuah kitab yang berunsur keagamaan berjudul Dawa' al-Qulub yang bermakna 'Ubat Hati'. Karya ini dihasilkan selepas kematian anak perempuannya Siti Lela yang ketika itu berusia lapan tahun. Menurut Abdullah:

Setelah sampailah aku ke Melaka, maka dalam dua tiga hari lamanya, maka telah berlakulah kehendak Allah di atas hambaNya, maka ia pun kembalilah ke Rahmatullah. ... Setelah sudah ditanamkan orang di masjid Keling di balik mihrab, maka ku ulang-ulangi kuburnya pada tiap-tiap hari serta percintaanku. Maka apabila aku lazimkanlah akan adat yang demikian, maka tergambar-gambarlah anakku itu di mataku. Hatta kepada suatu malam, ada kira-kira pukul setengah delapan pergilah aku seorang-orang diriku duduk di kuburnya serta dengan air mataku sambil ku renung-renung kuburnya itu. Tiba-tiba kulihat anakku itu seperti bermain di atas pasir itu. Maka segeralah aku pergi mendapatkan dia. Maka kulihat suatu pun tiada, hanya pasir. Maka ketahuilah bahawa Iblis rupanya hendak merosakkan aku. Maka pada saat itu juga bertaubatlah aku kepada Allah dengan tiada mau menaruh lagi percintaan dan menangiskan anakku itu. Maka pulanglah aku ke rumahku serta aku menegahkan isteriku daripada menangis dan menaruh percintaan. Maka kukatakanlah segala penglihatanku itu kepadanya. Maka memintalah kekasihku itu kepadaku sesuatu perkataan dan nasihat yang sahih supaya mengambil insaf ia akan dia.

... Maka daripada masa itu ku usahakanlah diriku mengarangkan suatu kitab yang ringkas. Maka kunamai akan dia dengan bahasa Arab, Dawa' al-Qulub, ertinya dalam bahasa Melayu, Ubat Hati. Maka adalah ku rencanakan dalam kitab itu dari hal peri kemuliaannya kepada ibu bapa yang mati anaknya sebelum baligh dan peri nikmat yang diperoleh ibu bapa kepada hari kiamat yang ada mati kecil-kecil itu dan perihal bagaimana besar dosanya bagi ibu bapa yang menaruh percintaan dan dukacita dan meratap dengan berbiji sabuk itu dan yang ada pula berlaku dengan berbagai-bagai kelakuan yang ditegahkan oleh syarak dan sebagainya. ${ }^{5}$

Abdullah memulakan kerjayanya di Melaka dan kemudiannya bersama-sama menyertai William Farquhar dan Stamford Raffles ke Singapura lalu menetap di sana. Menurut Abdullah, beliau pulang ke Melaka setiap enam bulan untuk mengunjungi keluarganya. Beliau 
banyak menghabiskan masa bersama-sama Raffles di samping menjadi jurutulis kepada pegawai British ini. Abdullah turut memperihalkan dalam karya ini peranan yang dimainkan oleh beliau dalam mengarang surat daripada Raffles kepada Maharaja Siam. Selain itu, Abdullah juga berkecimpung dalam bidang perniagaan di Singapura. Apabila isterinya meninggal dunia, Abdullah membawa kesemua anaknya dan terus menetap di Singapura. Abdullah meninggal dunia pada tahun 1854 ketika berusia 57 tahun dalam perjalanan menunaikan haji ke Mekah.

Berdasarkan keseluruhan pengalaman Abdullah yang diperihalkan, diiringi dengan kemahiran bahasa dan menulis, apatah lagi dalam lingkungan masyarakat yang masih buta huruf serta besar bilangannya, maka tidak hairanlah Abdullah dapat menghasilkan karya seumpama Hikayat Abdullah ini. Karya ini dimanfaatkan oleh beliau untuk melontarkan pandangan, pengalaman dan memperihalkan peristiwa berserta persepsi beliau terhadap sesuatu situasi mahupun individuindividu tertentu. Seperti yang dinyatakan sebelum ini, Abdullah bukanlah seorang kerabat diraja Melayu dan bukan seorang individu yang berperanan di sekitar istana. Oleh itu, dapat dilihat bahawa dorongan dan motif penulisannya tidak sama dengan pujangga Melayu terdahulu mahupun sezaman dengannya yang datang daripada kelompok berbeza. Selain itu, gaya penulisan Abdullah juga berlainan daripada yang sebelumnya.

Biarpun karya ini mengandungi isi-isi dari kaca mata yang berbeza (dianggap baru pada zamannya), gaya penulisan Hikayat Abdullah masih lagi memperlihatkan ciri-ciri tradisi. Beliau masih menggunakan bahasa Melayu klasik, masih banyak ayat dalam bentuk perbualan dan ayat pasif. Frasa-frasa awal klasik seperti syahdan, sebermula, hatta dan yang seumpama dengannya masih digunakan.

Keseluruhannya Hikayat Abdullah mengandungi 29 bab. Namun peristiwa-peristiwa yang dirawikan lebih banyak daripada bilangan bab itu sendiri. Pelbagai peristiwa termuat dalam karya ini. Selain memaparkan pengalaman peribadi ketika membesar, hal-ehwal keluarga dan pendidikannya, Abdullah turut memperihalkan episodepisod penting lain seperti pemecahan kota Melaka (Farmosa) oleh British, kedatangan Raffles ke Singapura, kedatangan Lord Minto ke Melaka, pengumpulan naskhah-naskhah Melayu oleh Raffles, penyerahan Melaka kepada Belanda oleh British, penubuhan sekolah Raffles di Singapura, kritikan terhadap sistem feudal Melayu, kisah dan pengalaman beliau dalam kem kongsi gelap, kepercayaan-kepercayaan kolot, Perang Candu dan beberapa episod lagi.

Abdullah juga sangat cenderung untuk memberi idea yang bersifat kritikan mahupun pujian terhadap sesuatu situasi misalnya kritikan terhadap raja dan masyarakat Melayu. Perkara yang disentuh 
seperti kezaliman dan kealpaan raja mahupun cara hidup raja-raja, kepercayaan karut-marut atau khurafat, adat resam yang tidak wajar dan ketinggalan zaman termasuk sikap sesetengah orang Melayu yang anti pemodenan dan sikap masyarakat Melayu yang bersangka buruk terhadap pembelajaran bahasa Inggeris. Kritikan-kritikan ini khususnya yang menjurus sikap raja dan kaum kerabatnya ditekankan lagi oleh Abdullah di halaman-halamam akhir (12 halaman kesemuanya). Karya ini seolah-olah merupakan satu kesimpulan terhadap keseluruhan pengarangannya.

\section{Kemasukan British ke Singapura}

Dalam tahun-tahun awal abad ke-19 memperlihatkan penglibatan British yang lebih menonjol dalam politik Kerajaan Johor. Sultan Mahmud (1761-1812) mangkat pada tahun 1812 dan meninggalkan dua orang putera yang kedua-duanya bukan anak gahara iaitu Tengku Husin (Tengku Long) dan Tengku Abdul Rahman. Akibat desakan Yang Di Pertuan Muda Raja Jaafar, Tengku Abdul Rahman diangkat menjadi pengganti bapanya sebagai sultan dan berkerajaan di Riau. Pada masa yang sama, pembesar-pembesar Melayu telah bermuafakat untuk menabalkan Tengku Husin memandangkan baginda anak yang sulong. Tengku Abdul Rahman sendiri pada asalnya tidak bersetuju dengan pelantikan baginda kerana mengikut adat dan wasiat, kekandanya Tengku Husinlah yang lebih berhak. ${ }^{6}$ Oleh kerana waktu itu Tengku Husin berada di Pahang, Yang Di Pertuan Muda Johor, Raja Jaafar bertindak cepat dan mengambil kesempatan mengangkat Tengku Abdul Rahman sebagai sultan bergelar Sultan Abdul Rahman Muazzam Syah. ${ }^{7}$ Tujuh tahun kemudian, British telah muncul di dalam politik Kerajaan Johor dengan melantik Tengku Husin sebagai sultan di Singapura pada 6 Februari 1819 (21 Rabiul Akhir 1234).

Tindakan British ini ekoran penyerahan semula Melaka kepada Belanda pada tahun $1818 .{ }^{8}$ British yang berkehendakkan pengkalan baru bagi perdagangan, politik dan keselamatan telah memandang Singapura sebagai tapak yang berpotensi. Selain itu, British gagal mendapatkan sokongan Raja Jaafar kerana beliau dan Sultan Abdul Rahman telahpun berbaik-baik semula dengan Belanda. Mereka juga telah menandatangani dan memperbaharui perjanjian yang pernah ditandatangani sebelumnya. Perjanjian ini ditandatangani pada 26 November 1818 di antara Yang Di Pertuan Muda Raja Jaafar dan Sultan Abdul Rahman dengan pegawai Belanda, Admiral Wolterbeek. ${ }^{9}$

Kenyataan ini terbukti melalui surat yang ditulis oleh Raffles kepada Gabenor Pulau Pinang, Kolonel Bannerman, bertarikh 1 Januari 1819. Antaranya menyebut, "The island of Singapore, or the district of 
old Johore, appears to me to posses peculiar and great advantages for the proposed settlement."10 Singapura mempunyai bekalan air yang kaya dan berpotensi sebagai pelabuhan yang terlindung daripada angin monsun. Kedudukannya di pintu masuk Selat Melaka juga strategik sebagai pusat perdagangan antara benua China dan Nusantara. Cuma Singapura perlu memiliki tradisi yang dimiliki oleh kerajaan-kerajaan sebelumnya seperti Melaka dan Srivijaya iaitu seorang sultan bagi pengiktirafan daerah tersebut di mata kerajaan Melayu yang lain. ${ }^{11}$

Selain meletakkan Singapura sebagai pengkalan perdagangan British yang baru ekoran Melaka yang diambil alih oleh Belanda semula, pemilihan Singapura juga dapat menghalang Belanda daripada mengambil alih terus pasaran perdagangan di Semenanjung Tanah Melayu khasnya dan di Nusantara amnya. ${ }^{12}$ Sememangnya British bimbang akan mengalami kesusahan dan kerugian dalam perdagangan di Timur apabila Melaka diambil alih oleh Belanda. ${ }^{13}$

Dua orang aktor British yang memainkan peranan utama sehingga berlakunya kemasukan pengaruh barat di Singapura ialah Thomas Stamford Raffles dan William R. Farquhar. Jelas bahawa dua watak British ini menjadi antara inti kepengarangan Hikayat Abdullah. Abdullah memberikan gelaran kepada Farquhar sebagai 'raja di Melaka' berdasarkan jawatan yang dipegang oleh beliau sebagai residen di Melaka antara 1803-1818. Sejak awal kemasukan British di Melaka, Farquhar menjadi jurutera kepada Mejar Cook yang berperanan mengepalai pengambilan Melaka dari Belanda sekitar 1795. ${ }^{14}$ Abdullah beberapa kali memuatkan episod yang membabitkan dasar atau pelaksanaan pentadbiran mahupun aktiviti harian Farquhar di Melaka. Contohnya diperihalkan dengan panjang lebar kisah pemecahan tembok/kubu Farmosa. ${ }^{15}$ Selain itu, sebuah bab yang berjudul 'Darihal Tuan Farquhar' diperuntukkan bagi menceritakan tentang diri Farquhar. ${ }^{16}$ Antara peristiwa lain yang menyentuh tentang Farquhar seperti peristiwa beliau ditembak oleh pengawal di rumahnya, kisah beliau menangkap gajah, tentang haiwan-haiwan peliharaan Farquhar (harimau, kucing hutan, anjing hutan, landak, burung kasuari, monyet, ungka, siamang, beruk dan pelbagai jenis burung) termasuk kisah Farquhar diserang harimau ketika sedang berkuda. Manakala keperibadian Farquhar turut diperincikan dengan jelas:

Bermula adalah tabiat Raja Farquhar itu, iaitu pendiam lagipun banyak sabar akan kesalahan orang. Dan lagi, baik miskin atau kaya sama juga kepadanya, tiada dipandangnya seorang lebih dan seorang kurang. Dan lagi, jikalau seorang miskin lagi hina sekalipun hendak datang mengadukan halnya, maka dengan segeranya didapatkannya dan didengarnya akan pengaduan orang itu serta 
diberinya nasihat dan diajarnya sampai menjadi sejuk orang itu punya hati, lalu pulanglah dengan sukacitanya. Dan lagi, jikalau ia berjalan atau berkereta atau berkuda, maka orang-orang miskin atau kaya dan kanak-kanak bertemu itu memberi tabik akan dia, maka dengan segeranya disahutnya. ${ }^{17}$

Menyusul di bab berikutnya, Abdullah memerihalkan pula tentang Raffles. Hubungan akrab beliau dengan pegawai British ini, menjadikan beliau sama sekali tidak berselindung dalam memaparkan kekagumannya terhadap Raffles. Perihalan tentang Raffles di dalam Hikayat Abdullah ternyata lebih banyak, meluas dan lebih ketara ciri biasnya. Bentuk tubuh badan Raffles juga turut diperincikan. Permulaan hubungan Abdullah dengan Raffles dicatatkan apabila Raffles mencari seorang jurutulis Melayu dan seorang yang boleh membantu beliau memahami 'surat dan hikayat-hikayat Melayu'. Sepertimana menggambarkan Farquhar, personaliti Raffles turut dicatatkan bagi memberi satu pandangan positif dan kagum pembaca terhadap watak kolonial ini. Hikayat Abdullah mencatatkan:

Syahdan, adalah tabiatnya itu ku lihat senantiasa di dalam berfikir juga. Maka terlalu pandai ia memberi hormat akan orang serta dengan manis mukanya berbahasa dengan orang, encik dengan encik, tuan dengan tuan. Dan lagi, banyak ia menaruh kasihan akan orang. Maka tangannya terbuka kepada orang miskin. Dan lagi, terlalu pandai ia membunuh perkataan orang. Dan lagi, selalu apabila ia bercakap, dengan tersenyum-senyum. ${ }^{18}$

$\cdots$

Adapun Tuan Raffles, itulah kesukaannya, senantiasa beramahramahan dengan orang Melayu. Jikalau orang miskin sekalipun, boleh juga bercakap dengan dia. ${ }^{19}$

Sebelum Raffles memilih pulau Singapura, William Farquhar telah membuat beberapa tinjauan ke beberapa kawasan lain. British merasakan perlu memberi perhatian terhadap misi Farquhar ke kawasan-kawasan lain bagi memastikan mereka dapat terus bebas berniaga di Timur. ${ }^{20}$ Gabenor Pulau Pinang, Kolonel Bannerman menegaskan tentang perlunya mereka mengamalkan dasar politik berbaik-baik dengan semua pembesar tempatan. Beliau juga menyebut tentang kegembiraan mereka terhadap kejayaan misi M. Cracorft ke Perak dan Selangor sehingga dapat membentuk perjanjian perdagangan terutama memonopoli timah di sana. Beliau berharap dasar itu dapat dikembangkan ke negeri-negeri Melayu lain. Justeru itu, cadangan Farquhar untuk mencari tapak perdagangan baru sama ada di Riau, Lingga, Pontianak atau Siak adalah dialu-alukan. ${ }^{21}$ 
Di dalam Hikayat Abdullah, Abdullah mencatatkan bahawa pada peringkat awal, misi Farquhar mencari dan meninjau wilayah-wilayah berpotensi tersebut dilakukan secara rahsia. Farquhar menggunakan helah untuk mencari dan menyelamatkan seorang wanita Inggeris yang kononnya ditawan oleh perompak di perairan Selat Melaka ketika belayar dari Pulau Pinang ke Melaka. Farquhar turut membawa bersama, “... empat lima orang Melayu peranakan Melaka serta seorang jurutulis namanya Encik Yahya bin Abdul Wahid, iaitu yang bergelar Encik Siang." 22

Rekod British melaporkan Farquhar pernah berkunjung ke Siak. ${ }^{23}$ Catatan dalam Hikayat Abdullah turut melengkapkan laporan ini apabila Abdullah menyebut, Farquhar telah ke Siak untuk memohon membuat pengkalan di Tanjung Jati. Namun begitu, cadangan ini ditangguhkan ekoran lokasi tersebut, "... apabila musim utara, terlalu amat besar ombaknya, tiada boleh tertahan kapal atau perahu berlabuh." ${ }^{24}$ Pada bulan September 1818, Farquhar telah melihat pula Pulau Karimun dan berminat dengannya. Sebelum itu, Hikayat Abdullah mencatatkan Farquhar turut meninjau ke Daik. Namun, Abdullah tidak pasti dengan hasil rundingan di Daik sehingga akhirnya Farquhar berkunjung pula ke Karimun. Selepas meninjau situasi, Farquhar telah menghantar sepucuk surat kepada Yang Di Pertuan Muda Raja Jaafar atas maksud membangunkan pengkalan British di Pulau Karimun. ${ }^{25}$ Raja Jaafar membalas surat itu pada 25 September 1818. Di dalam suratnya itu, Raja Jaafar membenarkan Farquhar membangunkan Pulau Karimun. ${ }^{26}$ Namun begitu, apabila dirujuk kepada Raffles, keputusan ini tidak diterima. ${ }^{27}$ Hikayat Abdullah memperincikan tentang kunjungan Farquhar ke Karimun tersebut sebagaimana berikut:
Maka naiklah ke darat serta melihat-lihat akan tempat dan gunung- gunungnya itu semuanya. Maka sukalah raja. Hatta daripada itu, pergilah pula mencari tempat pelabuhan. Maka didapati semuanya karang dan batu belaka, tiadalah dapat tempat kapal hendak berlabuh, lagipun diduga keliling Karimun itu terlalu dalam airnya. Dan lagi, tiada tempat kapal atau perahu-perahu hendak berlindung kalau angin ribut. Dan lagi, kalau sedikit salah, perahu kena karang. Maka sebab perkara yang tersebut itulah tiada menjadi. ${ }^{28}$

Namun, Abdullah tidak pula menyebut bahawa Farquhar merujuk kepada Raffles sebelum membatalkan keputusan memilih Pulau Karimun itu. Selain itu, Abdullah juga mencatatkan Farquhar singgah di Johor melihat kawasan tersebut sepulangnya dari Karimun sebelum kembali ke Melaka. ${ }^{29}$

Farquhar berikutnya berkunjung pula ke Pontianak atas motif yang sama. Di Pontianak, beliau mendapati kawasan ini telah mendapat 
pengaruh Belanda. Belanda juga telah menempatkan angkatan tenteranya yang besar dan kuat di sini. ${ }^{30}$ Di dalam Tuhfat al-Nafis juga ada menyebut tentang pelayaran Farquhar ke Pontianak. Menurut Tuhfat al-Nafis:

\begin{abstract}
Maka raja Melaka pun berlayarlah lalu ke Pontianak. Apabila sampai ke Pontianak pada malam hari, niat hatinya pada siang harinya ia hendak naik ke darat berjumpa dengan Sultan Pontianak. Tiba-tiba dilihatnya pada siang hari itu kapal-kapal perang Holanda banyak berlabuh di sebelah daratnya. Maka tiadalah ia jadi naik ke darat. ${ }^{31}$
\end{abstract}

Jelasnya, Farquhar dan Raffles mengambil kira banyak aspek dan potensi lokasi yang ditinjau sehingga akhirnya Singapura yang dipilih. Sumber Barat turut menyebut bahawa Farquhar telah belayar dan meninjau ke Siak, Pontianak, Lingga dan Riau dalam usaha pencarian tapak baru ini. ${ }^{32}$ Menurut Hikayat Abdullah juga, setelah penyerahan semula Melaka kepada Belanda, barulah Farquhar menuju ke Singapura. Abdullah memerihalkan bahawa Tengku Husin bukanlah orang yang asing dengan Farquhar malahan merupakan 'lama sudah bersahabat' dan Tengku Husin juga pernah meminjam wang Farquhar ketika beliau menjadi 'raja' di Melaka. ${ }^{33}$ Pakatan antara Raffles dengan Farquhar untuk menjadikan Singapura sebagai pengkalan British ini disampaikan Raffles kepada Gabenor Jeneral di Benggal. Raffles diberi jawapan sebagaimana yang dicatatkan oleh Abdullah,

Jikalau engkau hendak membuka negeri di Singapura itu boleh, tiada ditegahkan oleh kompeni, akan tetapinya belanja membuka negeri itu, kompeni tiada boleh beri melainkan wangmu sendiri berdua dengan Raja Farquhar itu. Syahdan, jikalau sudah jadi kelak, boleh kompeni fikirkan akan hal itu kemudian. ${ }^{34}$

Apabila mendapat jawapan yang sedemikian, Raffles lalu mengarahkan Farquhar belayar ke Singapura untuk membuat rundingan. Raffles sendiri terus ke Aceh kerana diarah menyelesaikan konflik dalaman di Aceh. ${ }^{35}$

Akhirnya Raffles dan Farquhar selesai membuat pemilihan dan mencapai kata putus untuk membangunkan Singapura. Namun sebelum menabalkan Tengku Husin, mereka terlebih dahulu membuat perjanjian dengan Temenggung Abdul Rahman iaitu pada 19 Ogos 1818. Dipercayai British perlu berkompromi dengan Temenggung memandangkan Temenggung telah lebih dahulu menetap di Singapura bersama-sama pengikut-pengikutnya. Malahan dikatakan kawasan penempatan yang didiami oleh orang Melayu dan Orang Laut di Singapura disebut orang sebagai Kampung Temenggung. ${ }^{36}$ Menurut 
Hikayat Abdullah, sebaik berlabuh di Singapura, Farquhar mendapati,

“... sebelah arah ke tepi sungai itu ada empat lima buah pondok-pondok kecil serta ada tanamannya enam tujuh batang pokok kelapa. Selain itu, terdapat juga sebuah rumah, sedikit besar, atap juga iaitu tempat Temenggung tinggal." 37

Pertemuan dan perbincangan berlaku di antara Farquhar dengan Temenggung dan lalu termeterai perjanjian bertarikh 30 Januari 1819. ${ }^{38}$ Di antara isi-isi perjanjian tersebut, menyebut British telah dibenarkan membina loji atau pengkalan mereka di Singapura dan kawasankawasan lain di bawah pengaruh Johor dan Singapura. Perjanjian ini juga memberi kelebihan kepada Temenggung iaitu British bersetuju untuk memelihara kepentingan Temenggung dan menghadiahkan tiga ribu rial setahun dari hasil keuntungan yang diperolehi British dari loji-loji mereka di Singapura. British juga berhak untuk menempatkan angkatan tenteranya di mana-mana kawasan di dalam Singapura sekaligus mengibarkan bendera mereka. ${ }^{39}$

Implikasi daripada perjanjian ini juga sebenarnya yang memberikan kelebihan kepada Temenggung di hari kemudian. Kebijaksanaan keluarga Temenggung memanfaatkan hubungan ini membolehkan mereka memperolehi banyak kelebihan sehinggalah akhirnya mengambil alih teraju takhta negeri Johor. Menurut Hikayat Abdullah, selepas mencapai kata putus dalam perbincangan di antara Temenggung dengan Farquhar, mereka telah menandatangani sepucuk surat yang berbunyi:

Ini surat tanda(h) suka Temenggung bersahabat dengan kompeni Inggeris serta dengan suka redhanya, jikalau ada dengan suka Tengku Long memberikan Pulau Singapura ini kepada kompeni Inggeris, iaitu kepada Tuan Raffles dan Tuan Farquhar akan diperbuat mereka itu negeri. ${ }^{40}$

Selepas daripada pakatan ini, Farquharpun menurunkan semua barang-barang dan pengikut-pengikutnya dari kapal lalu mendirikan sebuah kem petempatan di Singapura tersebut di tempat yang bernama Kampung Gelam. Abdullah berikutnya merawikan dengan agak terperinci suasana 'kem' yang dibina Farquhar dan pengikutnya tersebut. Abdullah turut menceritakan tentang tindakan Farquhar yang mengambil masa panjang untuk meninjau-ninjau kesesuaian Pulau Singapura sebagai pengkalan British.

Seperti yang tercatat dalam Hikayat Abdullah, berita tinjauan Farquhar ke Singapura dan cadangan British untuk mendirikan pengkalan di Singapura itu merebak dalam kalangan penduduk Melaka. Penduduk Melaka pula digambarkan oleh Abdullah sedang 
berada dalam keadaan tertekan ekoran Melaka yang telah diambilalih pentadbirannya oleh Belanda daripada tangan British. Berita tersebut menyebabkan penduduk Melaka mula memikirkan untuk turut serta berpindah ke Singapura mencuba kehidupan yang lebih baik. Teks ini mencatatkan, "Maka pada masa itulah juga ada kira-kira empat puluh anak-anak Melayu Melaka, anak-anak Kampung Jawa, semuanya mudamuda belaka hendak datang mencari ke Selat dalam sebuah perahu," ${ }^{41}$ namun kumpulan anak muda ini disebut kemungkinan besar dibunuh oleh perompak di perairan kerana tiada khabar yang diperolehi selepas itu. Kemudian Hikayat Abdullah menyambung, "banyak maranya di jalan, sebab masing-masing hendak mencari kehidupannya. Beratusratus orang Melaka datang juga ke Selat. Tambahan pula seksa di Melaka dengan tiada pencarian dan aniaya Holanda itu." 42 Petikanpetikan di atas menggambarkan bahawa pembangunan Singapura yang cuba diusahakan oleh Farquhar dan Raffles turut mendapat sokongan daripada penduduk Melaka yang berhijrah ke pulau itu.

Biarpun telah mencapai kata putus dengan Temenggung Abdul Rahman untuk melantik Tengku Husin sebagai sultan di Singapura, tetapi Farquhar tidak terus menjemput Tengku Husin dari Pulau Penyengat, Riau kerana beliau menunggu ketibaan Raffles dari Benggal. Oleh itu, setibanya Raffles di Singapura beberapa hari kemudian membawa empat buah kapal dan dua buah kici, lalu berlaku rundingan dan pakatan antara Farquhar, Temenggung dan Raffles dalam merangka strategi untuk mengambil Tengku Husin. Seorang yang bernama Raja Embung, dicatatkan oleh Abdullah sebagai salah seorang ahli keluarga Sultan Mahmud (ayahanda Tengku Husin) telah dijemput untuk bersama terlibat dalam pakatan ini. Menurut Hikayat Abdullah:

\footnotetext{
Setelah tetaplah bicara itu, maka seketika itu juga turunlah Raja Embung ke dalam sekoci lalu berlayarlah menuju Riau. Maka sehari semalam lamanya di laut, maka sampailah ke Riau di Kampung Penyengat pada tengah malam. Maka Raja Embung turunlah masuk ke dalam mengadap Tengku Long serta menceriterakan bahawa Tuan Raffles dan Tuan Farquhar serta Temenggung Abdul Rahman pinta silakan Tenku ke Selat karena hendak diangkat oleh mereka itu Tengku dijadikan sultan. Adapun mereka itu berkata-kata itu seorang dengan seorang sahaja. Maka demi didengar oleh Tengku Long akan khabar itu, maka hairanlah ia seraya termenung sejurus sebab menengar itu. ${ }^{43}$
}

Pada peringkat awal, Tengku Husin teragak-agak dengan undangan tersebut kerana khuatir akan ditipu oleh British. Namun atas kepercayaan baginda kepada Raja Embung, Tengku Husin bersetuju untuk berangkat ke Singapura. Pelayaran ini dilakukan secara rahsia 
supaya tidak diketahui oleh pihak lain termasuk Belanda. Menurut Hikayat Abdullah lagi, Tengku Husin disambut oleh Temenggung Abdul Rahman dan Farquhar setibanya baginda di Singapura. Manakala baginda menemui Raffles kemudiannya yang menanti di dalam kapalnya yang sedang berlabuh di perairan Singapura. Hikayat Abdullah memperincikan pertemuan di antara Tengku Husin dengan Raffles ini sekaligus menggambarkan betapa Raffles berusaha untuk mengambil hati dan menyakinkan Tengku Husin supaya proses pertabalan itu dapat dilaksanakan. Berdasarkan catatan Abdullah:

Kemudian maka Tengku Long dan Tuan Farquhar pun naiklah bersama-sama ke dalam sekoci itu. ... maka Tuan Raffles pun datanglah sendiri menyambut tangan Tengku Long itu. Maka meriam pun berbunyilah dari kapal-kapal dan kici itu, terlalu banyak. Maka Tuan Raffles pun mengunjukkan dengan sebaikbaik hormat dan ta'zim akan Tengku Long itu, dibawanya duduk di kerusi, keempat-empat mereka itu. Maka Encik Abu Putih pun duduk di belakang Tengku Long itu. Maka Raja Embung duduk jauh sedikit. Lalu bercakaplah Tuan Raffles pada masa itu dengan tersenyum-senyum simpul serta muka manis dengan menundukkan kepalanya, manis seperti laut madu. Maka pada masa itu, jangankan hati manusia, jikalau batu sekalipun, pecahpecahlah oleh sebab menengarkan perkataannya itu serta dengan lemah lembut suaranya, seperti bunyi-bunyian yang amat merdu. Akan menghilangkan percintaan dan syak yang ada tersembunyi dalam perbendaharaan hati manusia, itu pun lenyaplah. Maka segala ombak was-was yang berpalu-paluan yang di atas karang itu pun teduhlah. ... sehingga kelihatanlah tulus ikhlas Tuan Raffles akan Tengku Long itu.. ${ }^{44}$

Pertabalan Tengku Husin merupakan perkara yang sememangnya direncanakan oleh Raffles. Hikayat Abdullah secara jelas menceritakan apabila Temenggung memaklumkan Farquhar tentang situasi politik Johor, isu pertabalan Tengku Abdul Rahman dan kedudukan alat kebesaran kerajaan yang berada di tangan Tengku Hamidah (Engku Puteri - balu Sultan Mahmud) di Pulau Penyengat, Farquhar hanya tersenyum dan menyatakan, “Tengku [Temenggung], adapun segala perkara itu semuanya sudah ada dalam hati Tuan Raffles. Ia boleh betulkan." ${ }^{45}$ Peristiwa pertabalan Tengku Husin sebagai Sultan Singapura, Johor dan pulau-pulau sekitarnya turut dicatatkan di dalam Tuhfat al-Nafis. Tuhfat al-Nafis menyebut bahawa proses pertabalan ini merupakan hasil pakatan di antara Farquhar denganTtemenggung Johor, Temenggung Abdul Rahman. Proses pertabalan ini dirancangkan dengan sulit bagi membolehkan Tengku Husin dibawa keluar dari Pulau 
Penyengat ke Singapura. ${ }^{46}$ Kenyataan Hikayat Abdullah turut seiring dengan catatan Tuhfat al-Nafis yang menyebut:

semasa Raffles tiba di Singapura, Tengku Husin masih berada di Pulau Penyengat, Riau. Dalam masa yang sama Yang Di Pertuan Muda Johor dan Sultan Abdul Rahman pula berada di Lingga. Oleh itu Raffles dan Farquhar telah berpakat dengan Temenggung Abdul Rahman lalu menghantar wakil mereka (yang disebut Raja Embung dalam Hikayat Abdullah) ke Riau untuk membawa keluar Tengku Husin ke Singapura secara rahsia. ${ }^{47}$

Hikayat Abdullah berikutnya memperihalkan dengan panjang lebar istiadat dan proses pertabalan Tengku Husin. Tengku Husin dipakaikan pakaian kerajaan manakala pegawai-pegawai British yang tiba bersamasama Raffles sebelum ini bersedia menanti di padang upacara. Tengku Husin diarak beriringan dengan Temenggung, Raja Embung dan pembesar Melayu yang lain. Tengku Husin turut dipayungkan dengan payung kuning. Tengku Husin juga turut diberikan penghormatan oleh pegawai-pegawai British. Kemudiannya seorang pegawai muda British membaca kalimah-kalimah Inggeris dari gulungan surat disusuli oleh Encik Yahya yang membaca kalimah-kalimah Melayu yang berbunyi:

Bahawa ketahuilah oleh segala orang, maka Tuan Gabenor Jeneral yang di Benggala mengangkat sultan akan Tengku Long dan digelar akan dia Sultan Husin Syah ibni Almarhum Sultan Mahmud Syah dalam negeri Singapura ini serta daerah teluk rantau jajahannya. ${ }^{48}$

Tuhfat al-Nafis turut menyebut, British menabalkan Tengku Husin dengan adat istiadat dan alat kebesaran agar pertabalan ini turut mendapat pengiktirafan masyarakat Melayu. Misalnya, apabila Tengku Husin sampai ke Singapura, "Maka berjumpa Tuan Raffles, maka dihormatilah sebagaimana adat menghormatkan raja-raja. Dipasangkan meriam, dipukulkan tambur dan lain-lainnya." ${ }^{49}$ Upacara pertabalan ini juga dilaksanakan di hadapan orang-orang Melayu, Orang-Orang Laut dan pelabur-pelabur Cina. Pembesar-pembesar Melayu dan pegawaipegawai British yang diiringi dengan angkatan tentera khas, hadir dengan pakaian kebesaran masing-masing. ${ }^{50}$

British didapati bertindak bijak melalui pertabalan ini. Merajakan Tengku Husin di Singapura juga bermakna meletakkan seorang pemimpin tempatan di pulau tersebut yang boleh berhubungan dan berurusan politik dan ekonomi dengan British bagi mewakili rakyat Melayu. Justeru itu, pertabalan ini disusuli dengan perjanjian yang ditandatangani di antara British bersama Sultan Husin Syah dan Temenggung Abdul Rahman. Perjanjian ini secara keseluruhannya 
memberikan kepentingan kepada British dan pertuanan yang amat terhad kepada Sultan Husin. Menurut Hikayat Abdullah, sebelum termaktubnya perjanjian yang menggariskan fasal terperinci misalnya berhubung elaun tahunan kepada Tengku Husin, Raffles menghadiahkan baginda sejumlah seribu ringgit berserta sekayu kain sakhlat (kain baldu) hitam dan sekayu kain sakhlat kuning. Abdullah turut mencatatkan bahawa sultan akan menerima elaun atau gaji sejumlah empat ratus enam belas ringgit sebulan manakala Temenggung menerima sejumlah separuh daripadanya iaitu dua ratus lapan ringgit sebulan. ${ }^{51}$

Selanjutnya, Hikayat Abdullah menyambung pada hari tersebut juga perjanjian termerterai di antara Syarikat British (Raffles?) dengan Sultan Husin. Perjanjian ini sebenarnya merupakan perjanjian persahabatan di antara Raffles bagi pihak British dengan Sultan Husin dan Temenggung Abdul Rahman. Secara umum, British telah bersetuju untuk memberi perlindungan dan membayar sebanyak $\$ 5,000.00$ setiap tahun kepada Sultan Husin turun temurun selagi British menempatkan loji-lojinya di Singapura. Temenggung Abdul Rahman juga diberi perlindungan yang sama dan dibayar sebanyak $\$ 3,000.00$ setahun. Sultan Husin dan Temenggung Abdul Rahman juga perlu melindungi loji-loji British dan memerangi musuh-musuh British yang cuba mengancam loji-loji tersebut. Selain itu, sultan dan temenggung termasuk waris-warisnya tidak berhak untuk membuat sebarang perjanjian dengan kuasa-kuasa Eropah yang lain. Kerajaan British juga berhak mengutip cukai ke atas kapal-kapal yang masuk ke Singapura. ${ }^{52}$

Sedikit kelebihan yang diperoleh oleh Temenggung kerana bekerjasama di dalam perlantikan ini. Tertulis bahawa Temenggung Abdul Rahman berhak menerima separuh daripada cukai-cukai yang dipungut daripada rakyat. Namun, yang penting dalam Artikel 6 perjanjian ini menyebut, pelabuhan Singapura adalah tertakluk di bawah perlindungan dan peraturan yang disediakan oleh British. ${ }^{53}$

Sejurus selesai proses pertabalan dan memerterai perjanjian, Abdullah menyatakan bahawa Raffles terus belayar kembali ke Benggal meninggalkan Farquhar sebagai residen Singapura, Flint sebagai syahbandar dan Bernard (menantu Farquhar) sebagai majistret di Singapura. ${ }^{54}$ Bagi memastikan kedudukan baginda selesa di Singapura dan tidak diancam oleh Belanda, Sultan Husin dan Temenggung Abdul Rahman pernah meminta British untuk memaklumkan kepada Belanda dan Yang Di Pertuan Muda Johor di Riau tentang pelantikannya dan penguasaan mereka ke atas Singapura supaya tidak berlaku salah faham tentang hak masing-masing (Sultan Abdul Rahman dan Sultan Husin atau British dan Belanda). ${ }^{55}$ 
Tidak dinafikan, selepas pendudukan British di Singapura melalui tindakan mereka merajakan Tengku Husin, Singapura dikatakan membangun dengan pesat. Dalam masa empat bulan selepas peristiwa tersebut, penduduknya telah mencapai lima ribu orang termasuk orang Cina yang aktif membangunkan ladang gambir dan perniagaan lain. Sehingga November 1822, jumlahnya mencecah 10,000 orang terdiri daripada berbilang bangsa dan suku seperti Melayu, Bugis, Jawa, Cina dan Arab. Kaum Cina merupakan kaum yang teramai waktu itu. British menggalakkan kemasukan pedagang-pedagang asing ke dalam Singapura bagi merancakkan lagi perdagangan tanpa mengambil kira keutamaan masyarakat Melayu. ${ }^{56}$

Menurut Hikayat Abdullah, tidak berapa lama kemudian Sultan Husin dan Temenggung Abdul Rahman pernah menyuarakan kepada Farquhar tentang ketidakcukupan gaji bulanan mereka ekoran beban dan belanja pengurusan keluarga mahupun para pengikut mereka yang tinggi. Apabila Raffles kembali dari Benggal, aduan seumpama itu disampaikan pula kepada Raffles. Setelah beberapa hari berbincang dan dengan beberapa desakan, akhirnya Raffles bersetuju untuk menaikkan elaun sultan kepada seribu ringgit sebulan manakala temenggung sejumlah tujuh ratus ringgit. Jumlah ini kekal sehinggalah Crawford menggantikan kedudukan Farquhar di Singapura. ${ }^{57}$

Pada tahun 1823, perkhidmatan Farquhar sebagai residen Singapura tamat. Beliau diganti oleh John Crawford. ${ }^{58}$ Sejak awal pengarangannya, Abdullah sentiasa memerihalkan peri laku baik Farquhar. Justeru, apabila masuk kepada episod Farquhar yang bakal meninggalkan Singapura ke Eropah, Abdullah dengan penuh dramatik dan panjang lebar merawikan suasana, murung, sugul dan sedih penduduk Singapura atas pemergian pegawai kolonial itu. ${ }^{59}$ Kemudiannya, Abdullah juga tanpa berlindung memerihalkan perasaan tidak gembira penduduk Singapura terhadap pengganti Farquhar yang digambarkan:

Sebermula maka sepeninggal Tuan Farquhar belayar itu maka Tuan Crawfordlah pun memegang kerajaan negeri Singapura. Tetapi sungguhpun negeri itu ada beraja, maka rupanya dan rasanya seperti tiada. Seperti perkataan pantun, 'Sepuluh bintang bertabur bolehkah sama dengan bulan yang satu?' Maka ku lihat akan hal negeri Singapura daripada masa itu, seperti kelakuan perempuan kematian suaminya. Rambutnya pun kusut, mukanya pun masam, duduklah ia dengan dukacitanya karena serinya telah tiada. ${ }^{60}$

Secara asasnya, pertabalan Tengku Husin di Singapura menjadi permulaan perpecahan Kerajaan Johor. Perpecahan ini semakin ketara apabila pada 17 Mac 1824, British dan Belanda telah menandatangani 
satu perjanjian di London. Perjanjian ini menetapkan sempadan kuasa masing-masing (British dan Belanda) ke atas Alam Melayu dengan meletakkan suatu garisan melintang pada peta di bawah Singapura. Secara jelas, perjanjian ini menyebut British tidak mempunyai hak dalam sebarang urusan di Pulau Karimun, Batam, Riau (Bentan), Lingga dan pulau-pulau lain di selatan Singapura. Belanda pula tidak boleh mencampuri sebarang urusan di dalam Singapura dan seluruh bahagian utaranya. Melaka diserahkan semula kepada British dan Bencoolen (Bangkahulu) yang sebelum ini dalam pegangan Belanda. ${ }^{61}$ Ini bermakna Kerajaan Johor yang sebelum ini meliputi Johor, Riau, Lingga, Pahang, Singapura dan pulau-pulau lain di Kepulauan Melayu telah berpecah kepada dua. Sultan Abdul Rahman berkuasa di Kepulauan Riau-Lingga dan pulau-pulau sekitarnya, sementara Sultan Husin berkuasa di Singapura dan Johor.

Keadaan ini menyukarkan raja-raja Melayu di kedua-dua kawasan kerana hubungan kekeluargaan yang sedia ada dan erat. Misalnya Sultan Husin pernah diberi amaran oleh British agar mengeluarkan semua orangnya yang berada di Pulau Karimun bagi memastikan hubungan antara British dan Belanda tidak terjejas. ${ }^{62}$ Selain kuasa raja Melayu yang terbatas, Raja Jaafar juga tidak lagi menjadi Yang Di Pertuan Muda bagi Kerajaan Johor yang meliputi Johor-Riau-LinggaPahang dan jajahan-jajahan takluknya. Apabila Kerajaan Johor terpecah dua, kuasa Yang Di Pertuan Muda turut terbatas. Raja Jaafar hanya menjadi Yang Di Pertuan Muda bagi Kerajaan Riau-Lingga sahaja. Justeru apabila beliau meninggal dunia pada tahun 1833, puteranya Raja Abdul Rahman telah diangkat sebagai Yang Di Pertuan Muda Kerajaan Riau-Lingga yang kedua. ${ }^{63}$ Pembahagian ini juga menunjukkan, tidak wujud lagi jawatan Yang Di Pertuan Muda di dalam Kerajaan Johor dan Raja Jaafar merupakan Yang Di Pertuan Muda Johor terakhir.

Hasil tipu helah British, Singapura telah terlepas daripada tangan Sultan Husin pada 1824. Di dalam Hikayat Abdullah telah menceritakan bagaimana Crawford berdolak-dalih sehingga tidak membayar wang saraan kepada Sultan Husin dan Temenggung Abdul Rahman selama tiga bulan berturut-turut. Crawford menggunakan alasan bahawa pihak Syarikat British mengalami kesempitan wang ekoran peruntukan daripada Benggal tidak sampai. Kegagalan Crawford ini menyebabkan Sultan Husin dan Temenggung Abdul Rahman kesempitan wang dan terpaksa menanggung banyak hutang. ${ }^{64}$

Situasi terdesak yang dihadapi Sultan Husin dan Temenggung Abdul Rahman telah digunakan sebaik mungkin oleh Crawford. British menawarkan $\$ 30,000.00$ kepada sultan dan $\$ 15,000.00$ kepada Temenggung sekiranya Singapura diserahkan terus kepada British. 
Sultan dan Temenggung yang tersepit waktu itu telah bersetuju. Seperti yang dicatatkan di dalam Hikayat Abdullah:

\begin{abstract}
Maka adalah sahaya [Crawford] telah mendapat perintah daripada Tuan Besar yang Benggala, iaitu menyatakan kepada sahaya menyuruh minta segala perintah negeri Singapura ini pulang ke bawah perintah Kompeni Inggeris supaya jangan lagi berbahagibahagi perintah ... Dan lagi, Kompeni beri kepada Tuan Sultan sekarang juga tiga puluh ribu ringgit dan kepada temenggung lima belas ribu ringgit. Dan lagi, jikalau dengan suka Tuan Sultan hendak pindah ke negeri lain, Kompeni nanti kasi hadiah tiga puluh ribu ringgit lagi....

Maka berfikirlah mereka itu dengan sehabis-habis fikiran pada malam itu. Maka esoknya datanglah suruhan daripada sultan kepada Tuan Crawford mengatakan sultan serta temenggung redhalah akan perkataan tuan kelmarin itu. Maka apabila didengar oleh Tuan Crawford yang demikian itu, sukacitalah ia sebab barang dikehendakinya itu telah didapatinya. ${ }^{65}$
\end{abstract}

Akhirnya pada 2 Ogos 1824 (28 Zulhijjah 1239) termeterailah perjanjian antara Crawford bagi pihak British bersama Sultan Husin dan Temenggung Abdul Rahman. ${ }^{66}$

Di dalam Artikel 2 perjanjian ini menyebut bahawa seluruh Pulau Singapura termasuk pulau-pulau kecil dan laut dalam jarak sepuluh batu sekelilingnya diserahkan kepada British. Oleh itu, Artikel 3 pula menyebut Sultan Husin akan dibayar pampasan sebanyak \$33,200.00 dengan gaji bulanan berjumlah $\$ 1,300.00$. Temenggung Abdul Rahman pula diberi pampasan sebanyak $\$ 26,800.00$ dan gaji bulanan berjumlah \$700.00, seumur hidup mereka dan selagi mereka tinggal di Singapura. ${ }^{67}$ Perjanjian ini kemudian disahkan oleh 'Supreme Government' pada 19 Januari 1825. ${ }^{68}$ Hikayat Abdullah turut memperihalkan bahawa Crawford menghebahkan berita penyerahan tersebut kepada seluruh penduduk Singapura ('berkeliling Singapura dan Kampung Gelam') dengan mengumumkan:

Bahawa hendaklah diketahui oleh segala orang dalam negeri ini, maka adapun segala hukum dan perintah negeri Singapura ini semuanya telah pulanglah kepada Kompeni Inggeris. Maka seperti Sultan Husin Syah dan temenggung itu sekali-kali tiadalah lagi berkuasa. Maka jikalau tiada dengan perintah polis, tiadalah boleh sultan itu membuat barang suatu. ${ }^{69}$

Jelasnya, melalui perjanjian ini British berjaya mengambil alih sebahagian besar politik Kerajaan Johor dan seluruh Singapura. Tindakan British juga menyebabkan berlakunya persaingan di antara 
keluarga Temenggung Abdul Rahman dan Sultan Husin berpanjangan. Sememangnya sebelum kemangkatan Sultan Husin lagi, baginda tidak dipandang British sebagai sultan yang benar-benar berkuasa. Menurut British, Sultan Husin, "... failed to win the approval of the Peninsula Malays." 70 Dengan tindakan British menidakkan kedaulatan Raja Ali (putera Sultan Husin) sebagai Sultan Johor setelah kemangkatan Sultan Husin dan memberikan keistimewaan kepada Temenggung memungut separuh daripada cukai yang diperolehi dari ladang-ladang lada hitam, candu dan getah telah menyemarakkan lagi persaingan di antara dua keluarga tersebut. Secara tidak langsung, perjanjian ini juga telah meletakkan segala harta Sultan, Temenggung dan waris-waris mereka seperti tanah dan rumah yang tidak boleh dipindahkan di Singapura atau pulau-pulau sekitarnya perlu dilepaskan. ${ }^{71}$

\section{Kesimpulan}

Sebagai sebuah karya yang lahir dalam rantau Melayu, Hikayat Abdullah tetap merupakan sebuah sumber yang penting dalam mewakili sumber tempatan. Biarpun terhasil dalam pola penulisan yang berbeza berbanding karya historiografi Melayu terdahulu atau sezaman dengannya, Hikayat Abdullah tetap sarat dengan fakta dan maklumat kesejarahan yang tidak boleh dikesampingkan. Penulisnya sendiri yang mempunyai hubungan atau pertalian yang erat dengan pegawaipegawai British menyebabkan isu atau peristiwa yang melibatkan tindak-tanduk mahupun pelaksanaan dasar British dapat dicungkil melalui karya ini. Sememangnya peristiwa seperti kemasukan British di Singapura ini tidak dicatatkan dengan sedemikian meluas di dalam naskhah-naskhah pensejarahan Melayu yang lain berbanding Hikayat Abdullah.

Namun begitu, sebagai peneliti sejarah, penggunaan Hikayat Abdullah sebagai sumber tetap perlu dilakukan dengan berhati-hati. Ciri bias terhadap kolonial dan sentimen pesimis terhadap penguasa Melayu begitu ketara kelihatan dalam kepengarangan Abdullah. Oleh itu, unsur-unsur pengarangan yang bersifat tafsiran pengarang semata perlu diteliti sebelum diterima pakai.

Episod kemasukan British ke Singapura merupakan sebuah fakta yang sangat penting terhadap perjalanan sejarah tanah air. Keinginan, proses, rangka strategi dan tindakan British (melalui individu-individu tertentu) sangat penting untuk difahami. Justeru, Hikayat Abdullah ternyata bermanfaat dalam mengutarakan episod ini kepada pembaca supaya jelas dengan kebenaran sejarahnya. 


\section{Lampiran}

\section{Perjanjian Antara Thomas Stamford Raffles dengan Datuk Temenggung Abdul Rahman Seri Maharaja, 30 Januari 1819 (4 Rabiul Akhir 1234) (Versi Melayu)}

Bahawa inilah perjanjian Datuk Temenggung Seri Maharaja Abdul Rahman raja Singapura yang memerintah negeri Singapura dan sekelian tukun pulau mana yang di dalam perintahnya Singapura di dalam dia pun nama sendiri dan di dalam nama Seri Sultan Husin Muhamad Syah raja Johor dengan Seri Paduka Thomas Stamford Raffles, Leftenan Gabenor Bengkulu serta dengan segalah daerahnya wakil Seri Maharaja Gabenor Jeneral di Bengal yang Maha Mulia, maka dari sebab lama bersahabat dan berdagangan perniagaan antara Kompeni Inggeris dengan negeri-negeri daerah yang di bawah perintah negeri Singapura Johor itulah baik dibikinkan pekerjaan yang patut tiada boleh putus selama-lamanya.

1 Perkara yang pertama maka boleh Kompeni Inggeris membikin loji akan perduduk di Singpura atau lain-lain tempat yang di bawah perintah Singapura Johor.

2 Perkara yang kedua maka dari sebab itu Kompeni Inggeris berjanjian pelihara Datuk Temenggung Seri Maharaja.

3 Perkara yang ketiga dari hal tanah Kompeni mahu bikin loji perduduk, Kompeni boleh kasi pada satu tahun kepada datuk Temenggung Seri Maharaja tiga ribu rial.

4 Perkara yang keempat maka Datuk Temenggung ada perjanjian selama-lamanya yang Kompeni Inggeris boleh duduk dan pelihara seperti janji ini tiada ia boleh masuk bicara atau lepas masuk di dalam daerahnya pada segala bangsa yang lain daripada bangsa Inggeris.

5 Perkara yang kelima maka apabila datang Seri Sultan yang dijalan sampai di sini boleh habiskan seggala perkara-perkara hal perjanjian ini dan tetapi baiklah Kompeni Inggeris boleh pilih satu tempat mahu dinaikkan bala tenteranya dengan alat perkakasnya dan menaikkan bendera Kompeni Inggeris maka dari itu diturunkan tanda tangan dan cop kedua kita di dalam kertas ini titkala diperbuat surat ini kepada empat hari bulan Rabiul Akhir tahun 1234.

Tandatangan dan cop, Thomas Stamford Raffles.

Tandatangan dan cop, Datuk Temenggung Abdul Rahman Seri Maharaja.

Sumber: Muhamad Said, Buku Teriti Johor Dengan Pertambahannya, Johor Bahru: Lembaga Malaya Press, 1941. Lihat juga; 'Surat-Surat Perjanjian Lama', (Salinan simpanan Arkib Negara Cawangan Johor Bahru). 


\section{Perjanjian Antara Thomas Stamford Raffles Dengan Sultan Husin Muhamad Syah Dan Datuk Temenggung Abdul Rahman Seri Maharaja, 6 Februari 1819 (11 Rabiul Akhir 1234) (Versi Melayu)}

Bahawa inilah surat perjanjian sahabat bersahabat tanda muafakat antara Kompeni Inggeris yang diperbuat oleh Honourable Sir Thomas Stamford Raffles, Leftenan Gabenor Bengkulu serta segala daerahnya ialah wakil yang mutlak daripada Most Noble Francis Marquis Hastings, Gabenor Jeneral Bengal dan segala daerahnya taklukan di bawah bendera Kompeni Inggeris yang mulia dengan Sultan Husin Muhamad Syah yang bertakhta kerajaan di dalam negeri Johor dan Datuk Temenggung Seri Maharaja Abdul Rahman yang memerintah Singapura serta daerahnya.

\section{Fasal yang pertama}

Maka dari hal surat perjanjian dahulu daripada bulan Rabiul Akhir kepada timbul bulan empat hari yang diperbuat Sir Thomas Stamford di dalam nama Kompeni Inggeris dan yang diperbuat dan Temenggung Seri Maharaja Abdul Rahman yang memerintah Singapura dan daerahnya di dalam namanya sendiri dan di dalam nama Sultan Husin Muhamad Syah mengaku menentukan sekalian perkara di dalam janji itu.

\section{Fasal yang kedua}

Maka adalah lagi pula dari hal perjanjian itu dan dari tiada boleh rugi Sultan Husin Muhamad Syah sekarang ini atau ada belakang dari sebab perkaraperkara di dalam janji ini maka Kompeni Inggeris berjanji dan muafakat bayar kepada Sultan itu pada setahun lima ribu ringgit selama-lamanya Kompeni Inggeris menduduki tempat itu dengan loji di dalam tanah daerah taklukan marhum yang turun temurun kepada Sultan Husin Muhamad Syah itu dan lagi Kompeni Inggeris berjanji pelihara Sultan itu selama-lamanya dia duduk dekat tempat yang diperintah Kompeni Inggeris tetapi betul Sultan boleh mengerti Kompeni Inggeris di dalam janji sahabat bersahabat ini dan di dalam janji ini memeliharakan Sultan. Kompeni Inggeris tiada berjanji masuk di dalam bicara hal kerajaan atau pemerintah Sultan dan tiada dia janji berperang pada lain-lain negeri dari sebab mahu mendirikan adat perintahnya.

\section{Fasal yang ketiga}

Maka dari hal Datuk Temenggung Seri Maharaja Abdul Rahman yang memerintah Singapura serta daerahnya sudah di dalam perjanjian dahulu itu diperbuat kepada empat haribulan Rabiul Akhir ini sudah kasi masuk terima Kompeni Inggeris oleh dia membuat loji di Singapura atau lain-lain tempat di dalam daerah takluknya dan dari hal perjanjian Kompeni di dalam janji dahulu itu Kompeni bayarkan kepada Datuk Temenggung itu pada tiap-tiap tahun tiga ribu ringgit dan janji Kompeni oleh memelihara tanda sahabat bersahabat 
dengan Datuk Temenggung itu maka pada janji ini sekelian perkara di dalam perjanjian itu sekarang ini mengaku dan menentukan seperti yang tersebut di dalamnya.

\section{Fasal yang keempat}

Maka Sultan Husin Muhamad Syah dan Datuk Temenggung Seri Maharaja Abdul Rahman ada berjanji dan muafakat jikalau ada musuh seteru kepada kompeni di dalam lojinya atau di mana-mana ia duduk di dalam daerah taklukan Sultan dan Temenggung itu hendaklah ditolong atas kompeni.

\section{Fasal yang kelima}

Maka Sultan dan Temenggung itu muafakat serta berjanji dengan bersumpah tiada boleh dia atau dia pun anakatau dia pun waris gantinya di belakang tiada boleh membikin janji dengan lain-lain negeri dan tiada boleh dia benarkan masuk duduk lain orang putih baik dari Eropah baik Amerikan membikin loji atau bicara memerintah di dalam daerahnya selama-lamanya Kompeni Inggeris ada duduk di dalam itu dan selama-lamanya Kompeni Inggeris pun pelihara dan tolong atas Sultan dan Temenggung itu seperti yang tersebut di dalam surat perjanjian ini.

\section{Fasal yang keenam}

Maka segala orang yang ada di dalam loji Kompeni Inggeris dan segala orang yang suka pada kemudian hari duduk di bawah bendera Inggeris maka hendaklah tersebut di dalam surat buku Kompeni Inggeris oleh Kompeni Inggeris memerintah dan menghukumkan di atas semuanya orang itu.

\section{Fasal yang ketujuh}

Maka dari hal segala hukuman atas orang hitam di sebelah timur ini hendaklah dimuafakatkan kepada kemudian hari antara Kompeni Inggeris dengan Sultan dan Temenggung itu kerana pada sekarang ini tiada boleh tentu berapa banyak orang boleh duduk dekat Kompeni punya perintah dan berapa banyak lain orang itu pun adat.

\section{Fasal yang kedelapan}

Maka bendera Singapura itu adalah di dalam pelihara Kompeni Inggeris boleh Kompeni Inggeris memerintahkan segala perkara hasil dan cukai atas perahuperahu dan kapal yang masuk berniaga.

\section{Fasal yang kesembilan}

Maka dari hal hasil cukai yang kemudian hari di atas segala barang dagangan kapal atau perahu-perahu yang keluar masuk berniaga di Singapura oleh Datuk Temenggung Seri Maharaja boleh dia dapat bahagi dua dari hasil cukai segala perahu kapal orang hitam dan lagi oleh Kompeni Inggeris membayar sekelian belanja atas menjaga bandar terima hasil cukai itu. 
Maka dari itu kita menurunkan tandatangan serta cop kita kedua di dalam kertas ini

Diperbuat surat kepada sebelas hari bulan Rabiul Akhir tahun 1234 tersebut di negeri Singapura adanya. (Pada 6 Februari tahun 1819).

Tandatangan,

Sir Thomas Stamford Raffles.

Cop Syarikat Hindia Timur

Cop Sultan Husin Muhamad Syah

Cop Datuk Temenggung Abdul Rahman

Sumber: Muhamad Said, Buku Teriti Johor Dengan Pertambahannya, Johor Bahru: Lembaga Malaya Press, 1941.

\section{Perjanjian Antara Sultan Husin Muhamad Syah dan Datuk Temenggung Abdul Rahman Menyerahkan Pulau Singapura Dengan Laut Dan Selat Dan Pulau Kecil-Kecil Kepada Kerajaan Inggeris, 2 Ogos 1824 (versi Bahasa Melayu)}

Inilah surat muafakat dan perjanjian sahabat bersahabat antara Kompeni Inggeris serta Paduka Seri Sultan Johor dan Datuk Temenggung Johor itu maka didirikan akan surat perjanjian ini pada hijrah seribu dua ratus tiga puluh sembilan tahun pada enam haribulan Zulhijjah iaitu pada tahun seribu delapan ratus dua puluh empat pada dua haribulan Ogos iaitu antara Paduka Seri Sultan Husin Muhamad Syah dan Datuk Temenggung Abdul Rahman Seri Maharaja serta tuan Residen John Crawford Esquire wakil mutlak Gabenor Jeneral di Bengal iaitu Right Honourable William Pitt Lord Amherst, wakil mutlak Kompeni Inggeris yang memerintahkan segala negeri Hindia yang dalam perintah Kompeni Inggeris itu dan ialah yang menetapkan perjanjian itu adanya.

\section{Fasal yang pertama}

Bahawa tetaplah damai dan sahabat bersahabat antara Kompeni Inggeris dengan Paduka Seri Sultan Husin Muhamad dan Datuk Temenggung Abdul Rahman Seri Maharaja sampai kepada waris yang akan mengantikan keduanya selama-lamanya. 


\section{Fasal yang kedua}

Bermula maka perjanjian Paduka Seri Sultan Husin Muhamad Syah serta Datuk Temenggung Abdul Rahman Seri Maharaja itu serahkan pulau Singapura dengan laut dan selat dan pulau kecil-kecil iaitu sepuluh mile jauhnya berkeliling pulau Singapura itu menjadi milik kerajaan Kompeni Inggeris sampai kepada waris yang akan menggantikan dia selama-lamanya.

Fasal yang ketiga

Ada pun sebab pulau Singapura dan selat dan pulau kecil-kecil yang berkeliling pulau Singapura milik kerajaan Kompeni Inggeris seperti yang tersebut dalam fasal yang kedua tadi maka perjanjian Kompeni Inggeris akan membayar kepada Paduka Seri Sultan Husin Muhamad Syah tiga puluh tiga ribu dua ratus ringgit bulat pada sekalinya dan pada tiap-tiap bulan seribu tiga ratus ringgit bulat banyaknya pada seumur hidup Paduka Seri Sultan Husin Muhamad Syah itu lagi sebab milik kerajaan yang tersebut tadi itu maka perjanjian kompeni Inggeris membayar kepada Datuk Temenggung abdul Rahman Seri Maharaja dua puluh ribu delapan ratus ringgit bulat pada sekalinya dan pada tiap-tiap bulan tujuh ratus ringgit bulat pada seumur hidup Datuk Temenggung Abdul Rahman Seri Maharaja itu adanya.

Fasal yang keempat

Syahdan maka telah redhalah Paduka Seri Sultan Husin Muhamad Syah sebab perjanjian segala hal yang tersebut dalam fasal yang kedua dan yang ketiga tadi sudah terima tiga puluh tiga ribu dua ratus ringgit bulat seperti lagi seribu tiga ratus ringgit bulat pada bulan yang pertama turut perjanjian itu juga lagi pun Datuk Temenggung Abdul Rahman Seri Maharja sudah terima dua puluh enam ribu delapan ratus ringgit bulat dengan redhanya serta tujuh ratus ringgit bulat pada bulan yang pertama atas perjanjian telah tersebut dalam fasal yang kedua dan yang ketiga itu jua adanya.

\section{Fasal yang kelima}

Arakian maka perjanjian Kompeni Inggeris akan menyebut dan berlaku kepada Paduka Seri Sultan Husin Muhamad Syah dan Datuk Temenggung Abdul Rahman Seri Maharaja dengan hormat dan adat yang pada dengan pangkatnya yang mulia baik selama ia diam di pulau Singapura baik apabila ia pergi datang di Singapura adanya.

\section{Fasal yang keenam}

Bermula jikalalu Paduka Seri Sultan Husin muhamad Syah atau waris gantinya dan Datuk Temenggung Abdul Rahman Seri Maharaja atau waris gantinya berkehendak pindah dari Singapura serta diam tetap pada barang tempat lain di tanah milik Paduka Seri Sultan dan Datuk Temenggung itu maka perjanjian Kompeni Inggeris sebab pindah itu akan membayar kepada Paduka Seri Sultan Husin Muhamad Syah dua puluh ribu ringgit bulat banyaknya atau kepada waris gantinya dan kepada Datuk Temenggung Abdul Rahman Seri Maharaja atau waris gantinya lima belas ribu ringgit bulat banyaknya. 


\section{Fasal yang ketujuh}

Adapun sebab perjanjian yang tersebut dalam fasal yang keenam maka ditingalkan oleh Paduka Seri Sultan Husin Muhamad Syah dan Datuk Temenggung Abdul Rahman Seri Maharaja dan waris yang akan menggantikan keduanya selamanya iaitu segala harta miliknya yang tiada dipindahnya iaitu seperti tanahnya dan rumah-rumah dan kebun-kebun dan segala jenis kayu-kayu baik dalam pulau Singapura baik pada segala pulau taklukan Singapura itu diserahkan kepada tangan Kompeni Inggeris datang kepada warisnya yang akan menggantikan dia selama-lamanya iaitu daripada ketika pindahnya ke tanahnya di tempat lain tetapi mengertilah kedua pihak dengan tiada bersalahan bahawa segala harta pengiring dan orang Paduka Seri Sultan Husin Muhamad Syah dan Datuk Temenggung Abdul Rahman Seri Maharaja yang di luar sempadan tanah Paduka Seri Sultan Husin Syah dan Datuk Temenggung Abdul Rahman Seri Maharaja tiada tersebut dan tiada dimasukkan dalam fasal ini.

\section{Fasal yang kedelapan}

Maka perjanjian paduka Seri Sultan Husin Muhamad Syah dan Datuk Temenggungung Abdul Rahman Seri Maharaja dengan warisnya yang akan menggantikan keduanya kama selama ia diam di dalam pulau Singapura atau selama keduanya mengambil pembayar pada bulan daripada Kompeni Inggeris seperti yang tersebut dalam surat perjanjian ini maka tiada boleh ia atas barang pekerjaan dengan barang bangsa orang lain jikalau tiada dengan setahu Kompeni Inggeri atau warisnya yang akan menggantikan dia selamanya. Fasal yang kesembilan

Maka jikalau paduka seri Sultan Husin Muhamad Syah dan Datuk Temenggung Abdul Rahman Seri Maharaja itu berpindah ke Tanah milikannya dan jikalau datang barang susah atau bahaya di tempat itu maka perjanjian Kompeni Inggeris memberi perlindungan kepada dia di pulau Singapura atau di Pulau Pinang.

\section{Fasal yang kesepuluh}

Bermula maka perjanjian Inggeris tiada akan masuk pada barang hal daripada hukum adat yang pada tangan paduka Seri Sultan Husin Muhamad Syah dan Datuk Temenggung Abdul Rahman Seri Maharaja dan perjanjian paduka Seri Sultan Husin Muhamad Syah dan Datuk Temenggung Abdul Rahman Seri Maharaja itu tiada masuk pada barang pekerjaan daripada hukum adat yang dalam tangan kompeni Inggeris lagi pun perjanjian kedua pihak itu tiada kan memberi pertolongan satu sama lain pada barang hal pergaduhan atau perang dan tiada memberi bantu melawan susah dan tiada sedia dengan musuh kedua pihak adanya.

\section{Fasal yang kesebelas}

Syahdan maka perjanjian kedua pihak itu tolong menolong menangkap dan menghukumkan segala pencuri dan penyamun dan perompak baik di darat baik di laut iaitu pada segala tempat yang dalam perintah kedua pihak adanya. 


\section{Fasal yang kedua belas}

Maka perjanjian Paduka Seri Sultan Husin Muhamad Syah dan Datuk Temenggung Abdul Rahman Seri Maharaja memberi segala orang masuk keluar dan berniaga dengan tiada diberi susahan serta memberi pada segala orang Inggeris masuk keluaar dan berniaga pada segala negeri dan tempat yang takluk pada Johor seperti bangsa yang terlebih dikasihi iaitu daripada segala hukum adat dan kebajikan Paduka Seri Sultan Husin Muhamad Syah dan Datuk Temenggung Abdul Rahman Seri Maharaja.

\section{Fasal yang ketiga belas}

Maka selama Paduka SeriSultan Husin Muhamad Syah dan Datuk Temenggung Abdul Rahman Seri Maharaja diam dalam pulau Singapura maka perjanjian kompeni Inggeri jikalau orangnya atau pengiringnya lari atau meninggalkan pekerjaan Paduka Seri Sultan Husin Muhamad Syah atau Datuk Temenggung Abdul Rahman Seri Maharaja maka sekali-kali tiada diberinya orng itu diam atau duduk di pulau Singapura atau barang tempat yang takluk pada Singapura itu iaitu jikalau ia orang yang telah jadi dengan bantunya di tanah milik Paduka Seri Sultan Husin Muhamad Syah dan Datuk Temenggung Abdul Rahman Seri Maharaja yang dalam hukumnya pada sekarang ini dengan kenyataannya dan jikalau sudah dituliskan namanya dengan sukanya dan ketika ia masuk pekerjaan paduka Seri Sultan Husin Muhamad Syah dan Datuk Temenggung Abdul Rahman Seri Maharaja dalam daftar yang ditaruh oleh orang besar yang menjadi residen pada ketika itu.

\section{Fasal yang keempat belas}

Maka mengertikalah kedua pihak bahawa barang surat perjanjian yang telah ada antara kompeni Inggersi dengan Paduka Seri Sultan Husin Muhamad Syah dan Datuk Temenggung Abdul Rahman Seri Maharaja itu tiada terpakai lagi kemudian daripada hari ini melainkan kuasa yang diserahkan oleh Paduka Seri Sultan Husin Muhamad Syah dan Datuk Temenggung Abdul Rahman Seri Maharaja kepada Kompeni Inggeris akan mendirikan bendera Inggeri di dalam pulau Singapura seperti mana yang telah tersebut di dalam perjanjian yang dahulu itu jua adanya.

Terselesai di Singapura pada hari bulan dan tahun yang tersebut di atas itu.

Cop Sultan Husin Muhamad Syah

Cop Datuk Temenggung Abdul Rahman Seri Maharaja

Cop John Crawford, Residen Singapura

Sumber: Dato Haji Muhamad Said, Buku Teriti Johor Dengan Pertambahannya, Johor Bahru: Lembaga Malaya Press, 1941. 


\section{Petikan surat yang ditandangani oleh Sultan Husin atas perakuan penyerahan Singapura seperti yang terkandung di dalam Hikayat Abdullah}

Bahawa ini surat pada menyatakan, maka adalah kita Sultan Husin syah bin Almarhum Sultan Mahmud Syah, Sultan Johor dan Pahang, iaitu Sultan di negeri Singapura mengaku dalam surat ini bahawa sesungguhnya maka adalah dengan suka-suka hati kita telah menyerahkan negeri Singapura ini serta dengan perintah-perintahnya sekali kepada Kompeni Inggeris adanya. Syahdan lagi, adalah pula perjanjian Kompeni kepada sultan, maka jikalau kiranya sultan handak berpindah dari negeri Singapura ini ke negeri lain melainkan Kompeni memberi hadiah tiga puluh ribu ringgit dan kepada temenggung dua puluh enam ribu delapan ratus ringgit. Dan lagi, adalah perjanjian Kompeni Inggeris memberi belanja kepada kita pada sebulan seribu tiga ratus ringgit. Bermua adapun pemberian Kompeni Inggeris yangtersebut pada sebulan-sebuan itu, iaitu selagi ada hayat sultan sahaja. Bahawa surat perjanjian ini diperbuat dalam negeri Singapura kepada dua hari bulan Augustu tahun Masihi 1824.

Sumber: Abdullah bin Abdul Kadir Munsyi, Hikayat Abdullah, Jakarta: Penerbit Jambatan dan Gunung Agung, 1849, hlm. 304-305. (Jawi - Salinan simpanan Pusat Manuskrip Melayu, Perpustakaan Nasional Malaysia, MN899.23 ABD) $)^{72}$ 


\section{Nota}

$1 \quad$ Abdullah bin Abdul Kadir Munsyi, Hikayat Abdullah, Jakarta: Penerbit Jambatan dan Gunung Agung, 1849, hlm. 5. (Jawi - Salinan simpanan Pusat Manuskrip Melayu, Perpustakaan Nasional Malaysia, MN899.23 ABD)

Muhd. Yusof Ibrahim, Sejarawan dan Pensejarahan Melayu, Kuala Lumpur: Tinta Publishers, 2010, hlm. Xvii.

Abdullah bin Abdul Kadir Munsyi, Hikayat Abdullah, hlm. 316.

Ibid., hlm. 317-318.

Ibid., hlm. 395-397.

Charles B. Buckley, An Anecdotal History of Old Times in Singapore, Kuala Lumpur: Oxford University Press, 1965, hlm. 23.

7 CO 273/416, "Copy of the Treaty of 1855 between the Sultan of Johor and His Highness Tumonggong and for the Correspondence respective Muar since the Death of The Late Sultan Of Johor", William C.F. Robinson kepada Carnavon, 5 November 1877, Enclosure 2, Surat Tengku Alam bin Sultan Alli Iskandar Shah kepada Carnavon, 2 November 1877.

$8 \quad$ SSR G1, Surat dari Residen Melaka, William Farquhar kepada Raja Muda Riau, 15 September 1818/14 Zulkaedah 1233.

9 SSR B5, Surat Gabenor Pulau Pinang, Colonel Bannerman kepada Setiausaha Kerajaan di London, 8 Mac 1819.

10 W.H. Read, Play and Politics, London: Darton \& Company, 1901, hlm. 11.

11 Barbara W. Andaya dan Leonard Y. Andaya, Sejarah Malaysia, Petaling Jaya: Macmillan Publisher (M) Sdn. Bhd., 1983, hlm. 128: Lihat juga C.M. Turnbull, A History of Singapore 1819-1975, Kuala Lumpur: Oxford University Press, 1977, hlm. 9: C.E. Wurtzburg, Raffles of the Eastern Isles, London: Hodder and Stoughton, 1954, hlm. 478 dan 485. Frank Swetthenham, The Real Malay, London: John Lane The Bodley Head, 1899, hlm. 6.

SSR B5, Surat Gabenor Pulau Pinang, Colonel Bannerman kepada Setiausaha Kerajaan di London, 8 Mac 1819.

Abdullah bin Abdul Kadir Munsyi, Hikayat Abdullah, hlm. 9 dan 12.

Ibid., hlm. 45-47. Biarpun begitu, Abdullah kelihatan terkilan dan tidak bersetuju dengan tindakan pemecahan tembok tersebut sebagaimana katanya, "Banyak sungguh kepandaian dan hikmah orang putih ini. Akan tetapi terlalulah sayangnya kota sebagus ini dibinasakan dengan sebentar juga. Maka jikalau hendak dibaiki, entah berapa tahun belum lagi boleh jadi demikian. Adapun, seri negeri Melaka itulah kota itu. Maka apabila sudah pecah kota itu, maka negeri Melaka pun tiada berseri lagi, umpama seorang perempuan yang kematian suaminya, tiadalah berseri mukanya." Lihat, Abdullah bin Abdul Kadir Munsyi, Hikayat Abdullah, hlm. 47. Abdullah bin Abdul Kadir Munsyi, Hikayat Abdullah, hlm. 65-80.

Ibid., hlm. 75 .

Ibid., hlm. 82.

Ibid., hlm. 87. 
SSR B5, Surat Gabenor Pulau Pinang, Colonel Bannerman kepada Setiausaha Kerajaan di London, 8 Mac 1819.

21 SSR I18, Surat Gabenor Pulau Pinang, Colonel Bannerman kepada Residen Melaka, William Farquhar, 26 Jun 1818. Lihat juga SSR I18, Surat Gabenor Pulau Pinang, Colonel Bannerman kepada Residen Melaka, William Farquhar, 9 September 1818: SSR I18, Surat Gabenor Pulau Pinang, Colonel Bannerman kepada Residen Melaka, William Farquhar, 21 September 1818.

22 Abdullah bin Abdul Kadir Munsyi, Hikayat Abdullah, hlm. 176.

23 SSR G1, Surat Residen Melaka, William Farquhar kepada Raja Muda Riau, 15 September 1818/14 Zulkaidah 1233.

$24 \quad$ Abdullah bin Abdul Kadir Munsyi, Hikayat Abdullah, hlm. 177.

25 SSR G1, Surat Residen Melaka, William Farquhar kepada Raja Muda Riau, 15 September 1818/14 Zulkaidah 1233. SSR F1, Surat Raja Muda Riau kepada Residen Melaka, William Farquhar, 25 September 1818 / 24 Zulkaidah 1233.

R.J. Wilkinson, editor, Papers on Malay Subjects, Kuala Lumpur: Oxford University Press, 1971, hlm. 70 \& 71. Lihat juga; W.H. Read, Play and Politics, hlm. 12. Abdullah bin Abdul Kadir Munsyi, Hikayat Abdullah, hlm. 177. Ibid. SSR B5, Surat Gabenor Pulau Pinang, Colonel Bannerman kepada Setiausaha Kerajaan di London, 8 Mac 1819.

Tuhfat al-Nafis, Naskhah Terengganu, Shaharil Talib, penyelenggara, Kuala Terengganu: The House of Teuku Ismail Sdn. Bhd., 1991, hlm. 196.

C.E. Wurtzburg, Raffles of the Eastern Isles, hlm. 482.

Abdullah bin Abdul Kadir Munsyi, Hikayat Abdullah, hlm. 181.

Ibid., hlm. 182.

Ibid.

C.E. Wurtzburg, Raffles of the Eastern Isles, hlm. 484.

Abdullah bin Abdul Kadir Munsyi, Hikayat Abdullah, hlm. 183.

Buyong Adil, Sejarah Alam Melayu, Kuala Lumpur: Jabatan Pelajaran Persekutuan Tanah Melayu, 1952, hlm. 15.

'Surat-Surat Perjanjian Lama', (Salinan simpanan Arkib Negara Cawangan Johor Bahru). Lihat juga: Muhammad Said, Buku Teriti Johor Dengan Perkembangannya, Johor Bahru: Lembaga Malaya Press, 1941, hlm. 3-4: Buyong Adil, Sejarah Alam Melayu, hlm. 13-15: Muhammad Said Haji Sulaiman, Treaties and Agreements Affecting the State and Territory of Johore, Johor Bahru: The Government Printing Office, 1952, hlm. 6.

Abdullah bin Abdul Kadir Munsyi, Hikayat Abdullah, hlm. 186.

Ibid., hlm.199.

Ibid., hlm. 199-200.

Ibid., hlm. 203-204.

Ibid., hlm. 205-206.

Abdullah bin Abdul Kadir Munsyi, Hikayat Abdullah, hlm. 184.

Tuhfat al-Nafis, Naskhah Terengganu, hlm. 251. Peristiwa rancangan Stamford Raffles untuk menduduki Singapura termasuk usaha beliau 
meyakinkan Kerajaan British dan pakatannya dengan Farquhar ini dijelaskan lebih lanjut di dalam: C.M. Turnbull, A History of Singapore 1819-1975, hlm. 6-10: A.H. Hill, penterjemah, "The Hikayat Abdullah", JMBRAS, volume XXVIII, part 3, Jun 1955, hlm. 137-141.

SSR L4, Surat Residen Singapura, William Farquhar kepada Leftenan Gabenor di Bangkahulu, Stamford Raffles, 4 Julai 1820.

Abdullah bin Abdul Kadir Munsyi, Hikayat Abdullah, hlm. 208.

Tuhfat al-Nafis, Naskhah Terengganu, hlm. 201.

C.M. Turnbull, History of Singapore 1819-1975, hlm.10.

Jumlah gaji bulanan tersebut umumnya tidak dicatatkan di dalam perjanjian yang dimerterai berikutnya. Perjanjian ini hanya menyentuh tentang bayaran tahunan dan perkara-perkara lain seperti yang dibincangkan di atas.

Bagi pulau Singapura, dikatakan kawasan yang diliputi di dalam perjanjian ini ialah kawasan yang memanjang antara Tanjung Malang hinggalah ke Sungai Kallang. Lihat 'Historical Notes of Singapore, History of Telok Belangah', (Salinan simpanan Arkib Negara Cawangan Johor Bahru).

'Surat-Surat Perjanjian Lama'. Lihat juga 'Perjanjian/Treaties and Engagements', (Salinan simpanan Arkib Negara Cawangan Johor Bahru): Muhammad Said Haji Sulaiman, Buku Teriti Johor Dengan Pertambahannya, hlm. 5-8: Muhammad Said Haji Sulaiman, Treaties and Agreements Affecting the State and Territory of Johore, hlm. 8-10. (Lihat Lampiran). Abdullah bin Abdul Kadir Munsyi, Hikayat Abdullah, hlm. 209. SSR F2, Surat Sultan Husin dan Temenggung Abdul Rahman kepada residen Singapura, William Farquhar, 1 Mac 1819. Walter Makepeace, One Hundred Years of Singapore, volume 1, London: John Murray, Albenar Street, 1921, hlm. 79-80. Abdullah bin Abdul Kadir Munsyi, Hikayat Abdullah, hlm. 216-217. Apabila William Farquhar meletakkan jawatan sebagai residen Singapura pada Mei 1822, Crawford telah ditetapkan sebagai pengganti beliau. Crawford tiba di Singapura pada 27 Mei 1823 dan dilantik secara rasmi sebagai residen Singapura pada 29 Mei 1823. Lihat SSR L19, Surat S/U Kerajaan British kepada Residen Singapura, W. Farquhar, 22 Mei 1822 SSR L19, Surat S/U Kerajaan British kepada Residen Singapura, W. Farquhar, 27 Mei 1823. Maklumat lanjut tentang J. Crawford sila lihat Thavamani Devi Rajah, 'John Crawfurd: Residen of Singapore (1823-1826)', Academic Exercise, University of Malaya, Singapura, 1959; Walter Makepeace, One Hundred Years of Singapore, hlm. 79-80. Abdullah bin Abdul Kadri Munsyi, Hikayat Abdullah, hlm. 270-274. Ibid., hlm. 274-275.

61 Buyong Adil, Sejarah Singapura, Kuala Lumpur: Dewan Bahasa dan Pustaka, 1972, hlm. 98. 
63 Raja Jaafar amnya ialah Yang Di Pertuan Muda Kerajaan Johor yang ke-6. Namun apabila British dan Belanda bertindak membahagikan Kerajaan Johor, kuasa Yang Di Pertuan Muda hanya terbatas di dalam Riau-Lingga sahaja dan ini menjadikan beliau sebagai Yang Di Pertuan Muda Kerajaan Riau-Lingga yang pertama.

64 Abdullah bin Abdul Kadir Munsyi, Hikayat Abdullah, hlm. 301-302.

65 Ibid., hlm. 303. Hikayat Abdullah turut memetik kalimah-kalimah dari sepucuk surat yang dikeluarkan oleh Crawford untuk ditandatangani oleh sultan berhubung penyerahan tersebut.

66 Mardiana Nordin, Politik Kerajaan Johor 1718-1862, Johor Bahru: Yayasan Warisan Johor, 2008, hlm. 35.

67 "Perjanjian/Treaties and Engagements". Lihat juga Muhamad Said Haji Sulaiman, Buku Teriti Johor dengan Pertambahannya, hlm. 14-19: Muhamad Said Haji Sulaiman, Treaties and Agreements Affecting the State and Territory of Johore, hlm. 16-20. SSR A39, Surat Residen Singapura, John Prince kepada Gabenor Negeri-Negeri Selat, John Anderson, 7 September 1827. Terlampir, 'Perjanjian 2 Ogos 1824/28 Zulhijjah 1239': The Singapore Free Press, 26 Januari 1837.

Di dalam surat Sultan Husin kepada gabenor Negeri-Negeri Selat bertarikh 10 September 1829 mencatatkan bahawa baginda menuntut bayaran dari Kerajaan British berjumlah 33,000.00 untuknya dan \$20,000.00 untuk Temenggung. Menurut baginda, bayaran ini perlu dijelaskan sebagaimana yang dijanjikan oleh Crawford kepada mereka berdua. Oleh itu, secara logiknya kita boleh membuat kesimpulan bahawa wang pampasan yang dijanjikan oleh Crawford kepada kedua-dua pemerintah ini melalui perjanjian 2 Ogos 1824, masih belum dijelaskan sepenuhnya sehinggalah tahun 1829. Lihat SSR A61, Surat Sultan Husin kepada Gabenor NegeriNegeri Selat, Robert Fullerton, 10 September 1829. SSR A31, Surat Pemangku Residen Singapura, S.G. Bonham kepada Setiausaha Kerajaan di London, 15 Disember 1826.

69 Abdullah bin Abdul Kadir Munsyi, Hikayat Abdullah, hlm. 306.

70 A.C. Milner, 'The Malay Raja: A Study of Malay Political Culture in East Sumatera and the Malay Peninsula in the Early Nineteenth Century', Tesis Ph.D., Cornell University, U.S.A, 1977, hlm. 123.

71 Surat Temenggung Ibrahim kepada E.A. Blundell, Gabenor NNS, 2 Februari 1856, 'Letter Book of H.H. The Maharajah of Johore 1855-1868', (Salinan simpanan Arkib Negara Cawangan Johor Bahru). 